\title{
Morfometri Kokon Attacus atlas Hasil Pemeliharaan di Laboratorium
}

\author{
Cocoon Morphometry Attacus atlas has Grown in the Laboratory
}

\author{
Y.C. Endrawati dan A.M. Fuah
}

Departemen Ilmu Produksi dan Teknologi Peternakan,

Fakultas Peternakan Institut Pertanian Bogor

J1. Agatis Kampus IPB Darmaga Bogor, 16680

e-mail:y.cahya82@gmail.com

(Diterima: 13 Agustus 2011; Disetujui: 12 Desember 2011)

\begin{abstract}
ABSTRAK
Attacus atlas is one of the wild silkworms which is originated from Indonesia, which has economic value and high potency to be developed especially at the cocoon stage. These potential aspects for future developed include row material of silk fabrics, cosmetics, medical, and engineering materials. However, this potential has not been matched by productions level. Attacus atlas still live in nature with only $10 \%$ of cocoon production rate. In this study, A. atlas was reared in the laboratory to determine the different characteristics of Attacus atlas cocoon between rearing enviromntment as compared to which in nature. The results showed that the characteristics of the cocoon varies and influenced by humidity and temperature environments, place and behavior during making cocoon. Whole cocoon weight average of $6.37 \pm 1.07$ $\mathrm{g} /$ cocoon, weight of floss $(0.23 \pm 0.09 \mathrm{~g} / \mathrm{cocoon}$ or $5.82 \pm 3.86 \%)$, weight of shell cocoon $(0.62 \pm 0.35 \mathrm{~g} /$ cocoon or $11.95 \pm 3.38 \%)$, weight of pupa $(3.77 \pm 1.99 \mathrm{~g} /$ cocoon or $71.74 \pm 9.42 \%)$, length of cocoon $(54.30 \pm 5.74 \mathrm{~mm})$, the diameter of the cocoon $(22.26 \pm 2.60 \mathrm{~mm}$ posterior, $25.65 \pm 2.38 \mathrm{~mm}$ medial and $22.92 \pm 2.45 \mathrm{~mm}$ anterior), the cocoon circumference $(70.42 \pm 7.48 \mathrm{~mm}$ posterior, $80.70 \pm 10.69 \mathrm{~mm}$ medial and $72.19 \pm 12.81 \mathrm{~mm}$ anterior).
\end{abstract}

Keywords: Attacus atlas, characteristic of cocoon

\section{PENDAHULUAN}

Ulat sutera adalah serangga yang dapat menghasilkan serat sutera dari proses pengolahan kokon. Ulat sutera dikelompokkan menjadi dua yaitu, ulat sutera domestikasi dan liar. Ulat sutera domestikasi contohnya adalah Bombyx mori, sedangkan ulat sutera liar diantaranya adalah Attacus atlas. A. atlas adalah serangga holometabola dengan siklus hidup sempurna, dimulai dari fase telur, ulat (larva), pupa dan imago (ngengat). Pada fase pupa, A. atlas berada pada fase istirahat dan dilindungi kokon sebagai perlindungan dari serangan predator dan kondisi lingkungan yang ekstrim.

Kokon mempunyai nilai ekonomi yang tinggi karena merupakan bahan dasar kain sutera dan biomaterial (kosmetik, medis dan material teknik). Benang dari kokon A. atlas sudah diekspor ke Jepang sebagai bahan baku kimono, dasi, selendang, dan pakaian jadi.
Harga benang sutera A. atlas mencapai Rp 1,5 juta per kilogramnya dan harga ini adalah 20 kali lipat dari harga benang sutera $B$. mori. Jepang menyukai benang dari $A$. atlas karena lebih lembut dari benang sutera $B$. mori, warna eksotik, benang yang panjang, lembut, tidak mudah kusut, tahan panas, tidak menimbulkan rasa gatal, dan anti bakteri (Sihombing, 1999; Faatih, 2005; Sari, 2007). Kokon juga dapat dimanfaatkan sebagai biomaterial seperti kosmetik dan medis (Padamwar dan Pawar, 2004) dengan memanfaatkan protein penyusun kokon yaitu fibroin dan serisin (Fabiani et al., 1996).

Indonesia sangat berpotensi untuk pemeliharaan ulat sutera liar Attacus atlas karena iklimnya sesuai dengan daya hidup $A$. atlas. Indonesia juga mempunyai keanekaragaman jenis makanan untuk $A$. atlas sehingga makanan akan tersedia sepanjang tahun. Hal ini sesuai dengan sifat Attacus atlas yaitu polivoltin (banyak generasi dalam satu 
tahun) dan polifagus (memakan 90 genus tanaman dari 48 famili) (Peigler, 1989). Beberapa jenis makanan A. atlas antara lain adalah daun sirsak (Annona muricata), srikaya (Annona squamusa), teh (Camellia sinensis), kina (Chincoma siccirubra), dadap (Erythrina sp.), mangga (Mangifera indica L), jeruk (Citrus sp.), alpukat (Persea americana) dan lada (Piper sp.).

Potensi yang tinggi tersebut perlu didukung oleh tingkat produksi yang tinggi. Akan tetapi hal ini belum bisa dicapai karena kokon A. atlas masih diperoleh dari alam dengan tingkat produksi sampai mencapai kokon hanya sekitar 10\% (Situmorang, 1996). Hal ini terjadi karena adanya serangan predator dan kondisi iklim yang tidak terkontrol. Oleh sebab itu, daya hidup serangga ini perlu ditingkatkan melalui upaya budidaya yang benar agar produktivitasnya tinggi. Budidaya juga bertujuan untuk melestarikan A. atlas dari kepunahan, karena selama ini kokon masih diambil dari alam tanpa upaya pemeliharaan kembali. Budidaya di dalam ruangan diharapkan dapat meningkatkan keberhasilan menjadi kokon karena faktorfaktor lingkungan dapat dikendalikan.

Informasi tentang kokon juga masih terbatas pada kokon $B$. mori sehingga pemanfaatan kokon $A$. atlas belum banyak dilakukan. Kajian morfometri kokon A. atlas perlu dilakukan untuk mendapatkan informasi dasar yang berguna untuk proses pemanfaatan kokon A. atlas. Semakin tinggi bobot kulit kokon yang dihasilkan maka semakin baik kokonnya karena serat sutera yang dihasilkan akan semakin banyak (Indrawan, 2007). Hal ini berarti material yang dapat dimanfaatkan akan semakin tinggi sehingga nilai ekonominyapun akan meningkat. Oleh karena itu dalam penelitian ini akan dibandingkan morfometri kokon A. atlas hasil pemeliharaan di laboratorium dengan yang di alam.

\section{METODE}

Penelitian ini dilaksanakan dari Mei sampai Juli 2009. Penelitian dilakukan di Laboratorium Lapang Non Ruminansia dan Satwa Harapan (NRSH) Blok C, Departemen
Ilmu Produksi dan Teknologi Peternakan, Fakultas Peternakan, Institut Pertanian Bogor. Materi penelitian yang digunakan adalah ulat sutera liar Attacus atlas instar enam yang berasal dari Perkebunan Teh Walini Purwakarta.

Proses pemeliharaan ulat instar enam sampai pengokonan (proses membuat kokon) dilakukan di laboratorium. Ranting dan sedikit daun dimasukkan ke dalam kotak sebagai tempat ulat mengokon. Bagian atas dari kotak yang terbuka ditutup dengan kain kasa. Tujuannya supaya pada saat ngengat keluar dari kokon, ngengat tidak terbang kemanamana sehingga jenis kelaminnya dapat teridentifikasi. Ulat sutera liar instar enam yang telah siap mengokon dimasukkan ke dalam kotak pengokonan.

Ulat sutera liar (A. atlas) instar enam setiap hari diamati untuk mengidentifikasi ulat mengokon. Ulat yang telah selesai mengokon akan menghasilkan kokon matang. Kokon akan menempel pada daun atau ranting menggunakan floss. Kokon yang telah matang kemudian dibersihkan dari daun atau ranting yang menempel. Data pengamatan dan pengukuran kokon A. atlas digunakan sebagai data primer yang meliputi bobot kokon utuh (kokon dengan floss dan pupa), bobot kulit kokon (bobot tanpa floss dan pupa), bobot floss, bobot pupa, panjang kokon, diameter kokon, lingkar kokon, dan jenis kelamin ngengat. Pengukuran panjang dan diameter kokon dilakukan dengan menggunakan jangka sorong, sedangkan lingkar kokon dengan menggunakan benang yang kemudian diukur dengan penggaris. Identifikasi ngengat jantan atau betina dilakukan dengan melihat antena (Peigler, 1989).

Data yang diperoleh dianalisis menggunakan analisis deskriptif untuk mengetahui karakteristik morfometri kokon meliputi bobot kokon utuh, bobot kulit kokon, bobot floss, bobot pupa, panjang kokon, diameter kokon, dan lingkar kokon. Hasil analisis data disajikan dalam bentuk tabel yang berisi rataan masing-masing parameter yang diamati dan keragamannya. Dilakukan uji korelasi antara peubah yang diamati terhadap bobot kulit kokon utuh dan analisis regresi dengan 
menggunakan Minitab 14 (Mattjik dan Sumertajaya, 2006).

\section{HASIL DAN PEMBAHASAN}

\section{Bobot Kokon}

Karakteristik kokon merupakan salah satu karakter sutera yang penting karena kokon mempunyai nilai ekonomi yang tinggi. Salah satu karakter kokon adalah bobot kokon. Bobot kokon ada dua yaitu bobot kokon utuh (bobot dengan floss dan pupa) dan bobot kulit kokon (bobot kokon tanpa floss dan pupa). Keduanya menjadi hal yang sangat penting karena persentase bobot kulit kokon ditentukan dari perbandingan bobot kulit kokon terhadap bobot kokon utuh. Semakin tinggi bobot kulit kokon yang dihasilkan maka semakin tinggi serat sutera yang dihasilkan (Indrawan, 2007).

Penelitian ini menghasilkan rata-rata bobot kokon utuh sebesar $6,37 \pm 1,07 \mathrm{~g} /$ kokon . Hasil ini tidak berbeda nyata dengan hasil Awan (2007) dengan bobot kokon utuh sebesar 7,00 $\pm 1,5$ g/kokon. Kedua hasil tersebut masih dalam kisaran yang sama karena sama-sama hasil pemeliharaan diruangan dengan pakan daun teh dan dalam kondisi lingkungan yang hampir sama yaitu masih dalam kawasan Bogor (suhu dan kelembaban rata-rata di pagi hari $22,4^{\circ} \mathrm{C}$ dan $78,6 \%$, siang hari $27,4^{\circ} \mathrm{C}$ dan $55 \%$, serta sore hari $25^{\circ} \mathrm{C}$ dan $75 \%)$. Akan tetapi hasil tersebut lebih rendah dari bobot kokon yang diambil dari alam perkebunan teh di Purwakarta (sekitar 9 $\mathrm{g} /$ kokon), meskipun mempunyai kisaran suhu dan kelembaban yang hampir sama. Kisaran suhu dan kelembaban habitat asli di Purwakarta berkisar $24-30{ }^{\circ} \mathrm{C}$ dan $60 \%-80 \%$. Hal ini berarti bahwa hal yang menentukan bobot kokon tidak hanya kondisi suhu dan temperatur tetapi juga kondisi tempat dan perilaku pada saat mengokon. Secara alami, ulat $A$. atlas akan mengokon dengan cara menempel pada daun atau ranting, sedangkan pada penelitian ini maupun penelitian Awan (2007) tempat mengokonnya adalah kotak plastik yang diberi daun dan ranting. Hal ini memungkinkan ulat tidak mengokon secara maksimal karena tidak nyaman.

Hal tersebut juga dibuktikan dengan persentase bobot kulit kokon yang dihasilkan. Pada penelitian ini menghasilkan persentase bobot kulit kokon sebesar 60,19 $\pm 7,78 \%$ (Tabel 1), sedangkan hasil Baskoro (2008) sebesar 72,39 $\pm 6,12 \%$. Persentase bobot kulit kokon yang lebih kecil dalam penelitian ini lebih memperkuat bahwa tempat mengokon berpengaruh terhadap bobot kulit kokon, karena akan mempengaruhi perilaku mengokon. Dalam perhitungan persentase kulit kokon diatas, bobot pupa tidak diperhitungkan. Hal ini karena Baskoro (2008) tidak memasukkan bobot pupa dalam perhitungan persentase bobot kulit kokonnya.

\section{Bobot Floss dan Bobot Pupa}

Proses mengokon (membuat kokon) sangat tergantung pada kondisi lingkungan seperti suhu dan kelembaban, serta tempat untuk mengokon. Persyaratan utama untuk tempat pengokonan adalah kuat, struktur cocok untuk mengokon, mampu mengontrol kelembaban, memberi kemudahan untuk memperlakukan larva pada waktu mengokon (Atmosoedarjo et al., 2000). Penelitian ini menghasilkan bobot floss sebesar 0,23 $\pm 0,09$ $\mathrm{g} /$ kokon (Tabel 1), sedangkan hasil Baskoro (2008) bobot floss-nya sebesar $0,18 \pm 0,05$ $\mathrm{g} /$ kokon (berasal dari perkebunan teh di Purwakarta). Hasil tersebut menunjukkan bahwa bobot floss yang dihasilkan pada penelitian ini lebih besar dari bobot floss kokon yang diambil dari alam. Hal ini kemungkinan karena pada saat ulat akan mengokon, ulat tersebut tidak menemukan tempat yang nyaman untuk membuat kokon seperti halnya di alam, sehingga ulat akan membuat floss yang banyak supaya dapat menyangga tubuhnya hingga proses mengokon terbentuk sempurna. Bobot pupa yang dihasilkan pada penelitian ini sebesar 3,76 $\pm 1,99$ g/kokon (Tabel 1). Bobot pupa dipengaruhi oleh jenis pakan yang diberikan, kondisi lingkungan, dan manajemen pemeliharaan yang dilakukan. 
Tabel 1. Karakteristik kokon A. atlas hasil pengokonan di laboratorium lapang Fakultas Peternakan IPB

\begin{tabular}{|c|c|c|c|}
\hline \multirow[t]{2}{*}{ No. } & \multirow[t]{2}{*}{ Parameter } & \multicolumn{2}{|c|}{ Nilai } \\
\hline & & Rataan \pm SD & Min-Max \\
\hline 1. & Bobot Kulit Kokon (BKK) (g/kokon) & $0,62 \pm 0,35$ & $0,10-1,54$ \\
\hline 2. & Bobot Floss (BF) (g/kokon) & $0,23 \pm 0,09$ & $0,08-0,58$ \\
\hline 3. & Bobot Pupa (BP) (g/kokon) & $3,77 \pm 1,99$ & $0,49-8,20$ \\
\hline 4. & Panjang Kokon (PK) (mm) & $54,30 \pm 5,74$ & $41,04-68,28$ \\
\hline \multirow[t]{4}{*}{5.} & Diameter & & \\
\hline & $1 / 4$ bagian posterior $(\mathrm{D} 1)(\mathrm{mm})$ & $22,26 \pm 2,60$ & $16,16-28,05$ \\
\hline & Medial (D2) (mm) & $25,65 \pm 2,38$ & $21,35-31,20$ \\
\hline & $1 / 4$ bagian anterior (D3) (mm) & $22,92 \pm 2,45$ & $17,34-29,10$ \\
\hline \multirow[t]{4}{*}{6.} & Lingkar & & \\
\hline & $1 / 4$ bagian posterior $(\mathrm{L} 1)(\mathrm{mm})$ & $70,42 \pm 7,48$ & $57,00-85,00$ \\
\hline & Medial (L2) (mm) & $80,70 \pm 10,69$ & $80,00-97,00$ \\
\hline & $1 / 4$ bagian anterior $(\mathrm{L} 3)(\mathrm{mm})$ & $72,19 \pm 12,81$ & $70,00-88,00$ \\
\hline
\end{tabular}

Keterangan :

SD : Simpangan baku

Min-Max : Nilai minimum-maksimum

Kualitas bobot kokon sangat ditentukan oleh bobot kulit kokon, bobot floss dan bobot pupa. Bobot kulit kokon yang tinggi sangat bermanfaat dalam aplikasi selanjutnya seperti benang sutera dan biomaterial. Bobot floss menunjukkan kondisi lingkungan pada saat pengokonan. Bobot pupa mengindikasikan jenis kelamin ngengat yang akan keluar. Hasil penelitian ini menghasilkan bobot kulit kokon sebesar $0,62 \pm 0,35 \mathrm{~g} /$ kokon $(11,95 \pm 3,38 \%)$, bobot floss sebesar $0,23 \pm 0,09$ g/kokon $(5,82 \pm 3,86 \%)$ dan bobot pupa sebesar $3,77 \pm 1,99 \mathrm{~g} /$ kokon $(71,74 \pm 9,42 \%)$.

\section{Jenis Kelamin Ngengat}

Pada penelitian ini, identifikasi jenis kelamin ngengat akan dihubungkan dengan data bobot kokon. Hal ini sangat bermanfaat dalam identifikasi jenis kelamin secara cepat di tingkat peternak. Data yang diperoleh dari penelitian ini, didapatkan ngengat berjenis kelamin jantan sebesar 15 ekor $(37,5 \%)$ dan betina sebesar 25 ekor $(62,5 \%)$ dari total ngengat yang keluar (40 ekor). Ngengat dengan jenis kelamin jantan memiliki rata-rata bobot kokon 6,15 $\pm 1,16 \mathrm{~g} /$ kokon sedangkan ngengat dengan jenis kelamin betina memiliki rata-rata bobot kokon 7,06 $\pm 1,66 \mathrm{~g} /$ kokon. Hasil tersebut sesuai dengan Peigler (1989) bahwa kokon jantan relatif lebih kecil dibanding kokon betina.

\section{Panjang, Diameter dan Lingkar Kokon}

Pengukuran panjang, diameter dan lingkar kokon bermanfaat dalam menentukan bentuk kokon. Bentuk kokon merupakan salah satu karakter khas yang dapat digunakan untuk identifikasi varietas maupun spesies ulat sutera. Hasil penelitian ini menggambarkan bahwa kokon $A$. atlas berbentuk elip dengan rata-rata panjang kokon $54,30 \pm 5,74 \mathrm{~mm}$, diameter (anterior 22,26 $\pm 2,60 \mathrm{~mm}$, medial $25,65 \pm 2,38 \mathrm{~mm}$, posterior $22,92 \pm 2,45 \mathrm{~mm}$ ) dan lingkar kokon (anterior 70,42 $\pm 7,48 \mathrm{~mm}$, medial $80,70 \pm 10,69 \mathrm{~mm}$, posterior $72,19 \pm$ $12,82 \mathrm{~mm})$. Hasil ini tidak jauh berbeda dengan hasil Baskoro (2008) dengan rata-rata panjang kokon $53,30 \pm 5,20 \mathrm{~mm}$, diameter (anterior $21,70 \pm 2,20 \mathrm{~mm}$, medial $26,10 \pm 2,30$ $\mathrm{mm}$, posterior $23,00 \pm 2,50 \mathrm{~mm}$ ) dan lingkar kokon (anterior 64,20 $\pm 6,20 \mathrm{~mm}$, medial $81,80 \pm 7,10 \mathrm{~mm}$, posterior $68,70 \pm 7,30 \mathrm{~mm}$ ). Hasil ini menunjukkan bahwa ukuran kokon yang mempengaruhi bentuk kokon dalam satu spesies ulat sutera (dalam hal ini A. atlas) adalah sama. Variasi dari ukuran kokon dipengaruhi oleh varietas, musim pemeliharaan dan kondisi lingkungan pada masa panen (Atmosoedarjo et al., 2000). 


\section{Analisis Korelasi dan Regresi}

Analisis korelasi dilakukan untuk mengetahui hubungan antara dua peubah bebas (Mattjik dan Sumertajaya 2006). Pada Tabel 2 menjelaskan tentang korelasi peubahpeubah yang diamati terhadap kulit kokon ulat sutera liar (A. atlas) pada penelitian ini. Bobot kulit kokon memiliki tingkat korelasi dengan bobot floss sebesar 0,468. Hal ini berarti antara bobot kulit kokon dengan bobot floss memiliki korelasi yang positif sehingga peningkatan bobot kulit kokon akan diikuti oleh peningkatan bobot floss). Korelasi yang baik antara bobot kulit kokon dengan bobot floss adalah berkorelasi negatif. Jika bobot kulit kokon tinggi maka bobot flossnya rendah karena pada bobot kulit kokon yang tinggi terdapat serat sutera yang banyak. Artinya bahwa energi ulat sutera digunakan untuk membuat benang dan bukan untuk membuat floss. Hal ini tidak sesuai dengan hasil penelitian karena ulat mengalami gangguan, misalnya stres pada saat proses mengokon.

Bobot kulit kokon memiliki korelasi yang rendah terhadap lingkar tengah (medial) kokon $(0,354)$ dibandingkan dengan diameter tengah (medial) kokon $(0,574)$ ataupun panjang kokon $(0,598)$. Bobot kulit kokon memiliki tingkat korelasi yang cukup tinggi dengan bobot kokon utuh dengan nilai sebesar 0,884 . Model persamaan regresinya yaitu $\mathrm{BKK}(\mathrm{g})=-0,0027+0,118 \mathrm{BKU}(\mathrm{g})$ dimana BKK adalah bobot kulit kokon dan BKU adalah bobot kokon utuh. Hasil tersebut berarti bahwa setiap kenaikan satu gram bobot kokon utuh akan meningkatkan bobot kulit kokon sebesar 0,118 g. Bobot kulit kokon (BKK) memiliki tingkat korelasi dengan panjang kokon (PK) dengan nilai sebesar 0,598 . Model Persamaan regresinya yaitu BKK $(\mathrm{g})=-1,37+0,0366$ PK $(\mathrm{mm})$, yang berarti bahwa setiap kenaikan satu mm PK akan meningkatkan BKK (g) sebesar 0,0366 g.

Bobot kulit kokon (BKK) memiliki tingkat korelasi dengan diameter medial (tengah) (D2) dengan nilai sebesar 0,574. Model persamaan regresinya yaitu BKK $(\mathrm{g})=$ $-1,55+0,0845$ D2 $(\mathrm{mm})$, yang berarti bahwa setiap kenaikan satu $\mathrm{mm}$ D2 akan meningkatkan BKK $(\mathrm{g})$ sebesar $0,0845(\mathrm{~g})$. Bobot kulit kokon (BKK) memiliki tingkat korelasi dengan lingkar medial (tengah) (L2) dengan nilai sebesar 0,354 . Model persamaan regresinya yaitu BKK $(\mathrm{g})=-0,321+0,0116$ L2 (mm), yang berarti bahwa setiap kenaikan satu mm L2 akan meningkatkan BKK (g) sebesar 0,0116 (g).

\section{KESIMPULAN}

Penelitian ini menghasilkan bobot kokon utuh rata-rata $6,37 \pm 1,07 \mathrm{~g} /$ kokon, bobot floss $(0,23 \pm 0,09 \mathrm{~g} /$ kokon atau $5,82 \pm 3,86 \%)$, bobot kulit kokon $(0,62 \pm 0,35$ g/kokon atau $11,95 \pm 3,38 \%)$, bobot pupa $(3,77 \pm 1,99$ $\mathrm{g} /$ kokon atau $71,74 \pm 9,42 \%$ ), panjang kokon $54,30 \pm 5,74 \mathrm{~mm}$, diameter kokon (posterior $22,26 \pm 2,60 \mathrm{~mm}$, medial $25,65 \pm 2,38 \mathrm{~mm}$ dan anterior $22,92 \pm 2,45 \mathrm{~mm}$ ), lingkar kokon

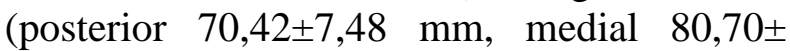
$10,69 \mathrm{~mm}$ dan anterior $72,19 \pm 12,81 \mathrm{~mm})$. Secara umum bobot kulit kokon berkorelasi positif dengan bobot kokon, panjang, diameter dan lingkar kokon dengan nilai korelasi yang bervariasi. Karakter morfometri hasil penelitian ini secara umum tidak berbeda nyata dengan morfometri kokon yang diambil di alam. Hal ini berarti bahwa upaya budidaya mempunyai propek yang baik dalam pengembangan ulat sutera liar A. atlas. Perlu kajian khusus tentang menejemen kandang dan pakan, untuk mengetahui sejauh mana pengaruhnya terhadap morfometri kokon $A$. atlas.

\section{DAFTAR PUSTAKA}

Atmosoedarjo, S., Kartasubrata, J., Kaomini, M., Saleh, W., Moerdoko, W. 2000. Sutera Alam Indonesia. Jakarta: Yayasan Sarana Wana Jaya.

Awan, A. 2007. Domestikasi ulat sutera liar Attacus atlas (Lepidoptera: Saturniidae) dalam usaha meningkatkan persuteraan nasional [disertasi]. Bogor: Program Pascasarjana, Institut Pertanian Bogor.

Baskoro, A. 2008. Karakteristik kulit kokon segar ulat sutera liar (Attacus atlas) dari 
perkebunan teh di daerah Purwakarta [skripsi]. Bogor: Fakultas Peternakan, Institut Pertanian Bogor.

Fabiani, C., Pizzichini, M., Spadoni, M., Zeddita, G. 1996. Treatment of waste water from silk degumming processes for protein recovery and water reuse. Desalination 105:1-9.

Faatih, M. 2005. Aktivitas antimikrobia kokon Attacus atlas. J Penelitian Sains dan Teknologi 6(1):35-48.

Indrawan, M. 2007. Karakter sutera dari ulat jedung (Attacus atlas L.) yang dipelihara pada tanaman pakan senggugu (Clerodendron serratum Spreng). $J$. Biodiversitas 8(3):215-217.

Mattjik, A.N., Sumertajaya I.M. 2002. Perancangan percobaan dengan aplikasi SAS dan minitab jilid 1. Bogor: IPB Press.
Padamwar, M.N., Pawar, A.P. 2004. Silk sericin and its applications. J Scientific and Industrial Research 63:323-329.

Peigler, R. 1989. A Revision Of The IndoAustralian Genus Attacus. California: The Lepidoptera Research Foundation, Inc. Beverly Hill.

Sari. 2007. Benang ulat sutra liar diekspor ke Jepang. http://www2.kompas.com/kompascetak/ 0711/09/jogja/1044437.htm [31 Janu-ari 2009].

Sihombing, D.T.H. 1999. Satwa Harapan I. Bogor: Pustaka Wirausaha Muda.

Situmorang, J. 1996. An attemp to produce Attacus atlas L. using baringtonia leaves as plant fooder. International J. Wild Silkworm and Silk.

Tabel 2. Korelasi peubah yang diamati terhadap kulit kokon ulat sutera liar (A. Atlas) hasil pengokonan di laboratorium lapang Fakultas Peternakan IPB

\begin{tabular}{|c|c|c|c|c|c|c|c|}
\hline & $\begin{array}{c}\text { BKU } \\
(\mathrm{g})\end{array}$ & $\begin{array}{c}\text { BKK } \\
(\mathrm{g})\end{array}$ & $\begin{array}{l}\text { BF } \\
\text { (g) }\end{array}$ & $\begin{array}{l}\text { BP } \\
\text { (g) }\end{array}$ & $\begin{array}{c}\text { PBKK } \\
(\%)\end{array}$ & $\begin{array}{l}\text { PBF } \\
(\%)\end{array}$ & $\begin{array}{l}\text { PBP } \\
(\%)\end{array}$ \\
\hline BKK (g) & 0,884 & & & & & & \\
\hline $\mathrm{BF}(\mathrm{g})$ & 0,568 & 0,468 & & & & & \\
\hline BP (g) & 0,972 & 0,828 & 0,535 & & & & \\
\hline PBKK (\%) & $-0,105$ & 0,305 & $-0,053$ & $-0,153$ & & & \\
\hline PBF (\%) & $-0,768$ & $-0,657$ & $-0,081$ & $-0,738$ & 0,217 & & \\
\hline PBP $(\%)$ & 0,076 & $-0,042$ & $-0,019$ & 0,288 & $-0,263$ & $-0,069$ & \\
\hline PK (mm) & 0,658 & 0,598 & 0,624 & 0,621 & 0,031 & $-0,350$ & $-0,001$ \\
\hline \multicolumn{8}{|l|}{ Diameter } \\
\hline - $\quad \mathrm{D} 1(\mathrm{~mm})$ & 0,569 & 0,509 & 0,462 & 0,586 & $-0,005$ & $-0,322$ & 0,198 \\
\hline $\mathrm{D} 2(\mathrm{~mm})$ & 0,613 & 0,574 & 0,475 & 0,632 & 0,069 & $-0,351$ & 0,225 \\
\hline - $\quad \mathrm{D} 3(\mathrm{~mm})$ & 0,626 & 0,622 & 0,408 & 0,635 & 0,103 & $-0,378$ & 0,183 \\
\hline \multicolumn{8}{|l|}{ Lingkar } \\
\hline $\mathrm{L} 1$ (mm) & 0,553 & 0,505 & 0,388 & 0,539 & $-0,038$ & $-0,367$ & 0,060 \\
\hline L2 (mm) & 0,395 & 0,354 & 0,323 & 0,385 & 0,034 & $-0,174$ & 0,016 \\
\hline L3 (mm) & 0,210 & 0,223 & 0,205 & 0,205 & 0,106 & $-0,006$ & 0,010 \\
\hline
\end{tabular}

